\title{
Central regulation of breast cancer growth and metastasis
}

\author{
Jeremy C. Borniger \\ Department of Psychiatry \& Behavioral Sciences, Stanford University School of Medicine, P154 MSLS Building, 1201 Welch Rd., \\ Stanford, CA 94305, USA.
}

Correspondence to: Dr. Jeremy C. Borniger, Department of Psychiatry \& Behavioral Sciences, Stanford University School of Medicine, P154 MSLS Building, 1201 Welch Rd., Stanford, CA 94305, USA. E-mail: jcbornig@stanford.edu

How to cite this article: Borniger JC. Central regulation of breast cancer growth and metastasis. J Cancer Metastasis Treat 2019;5:23. http://dx.doi.org/10.20517/2394-4722.2018.107

Received: 23 Dec 2018 First Decision: 5 Feb 2019 Revised: 13 Feb 2019 Accepted: 21 Feb 2019 Published: 28 Mar 2019

Science Editor: William Schiemann Copy Editor: Cai-Hong Wang Production Editor: Huan-Liang Wu

\begin{abstract}
Cancer is a systemic disease. In order to fully understand it, we must take a holistic view on how cancer interacts with its host. The brain monitors and responds to natural and aberrant signals arriving from the periphery, particularly those of metabolic or immune origin. As has been well described, a hallmark of cancer is marked disruption of metabolic and inflammatory processes. Depending on the salience and timing of these inputs, the brain responds via neural and humoral routes to alter whole-body physiology. These responses have consequences for tumor growth and metastasis, directly influencing patient quality of life and subsequent mortality. Additionally, environmental inputs such as light, diet, and stress, can promote inappropriate neural activity that benefits cancer. Here, I discuss evidence for brain-tumor interactions, with special emphasis on subcortical neuromodulator neural populations, and potential ways of harnessing this cross-talk as a novel approach for cancer treatment.
\end{abstract}

Keywords: Breast cancer, hypothalamus, immunometabolism, sympathetic nervous system, neuromodulators

\section{INTRODUCTION}

Uncovering the relationships among cancer and the physiology of its host has cemented the notion that cancer is a systemic disease. Cancer patients frequently experience systemic symptoms like depression, sleep disruption, cognitive impairment, appetite and metabolic dysfunction, and weight loss. These phenomena span different cancer types and occur independently from treatment regimens. Clinical studies consistently report that such symptoms (such as weight loss, sleep disruption, and circadian misalignment) are predictors

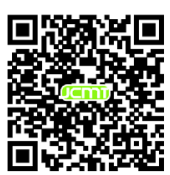




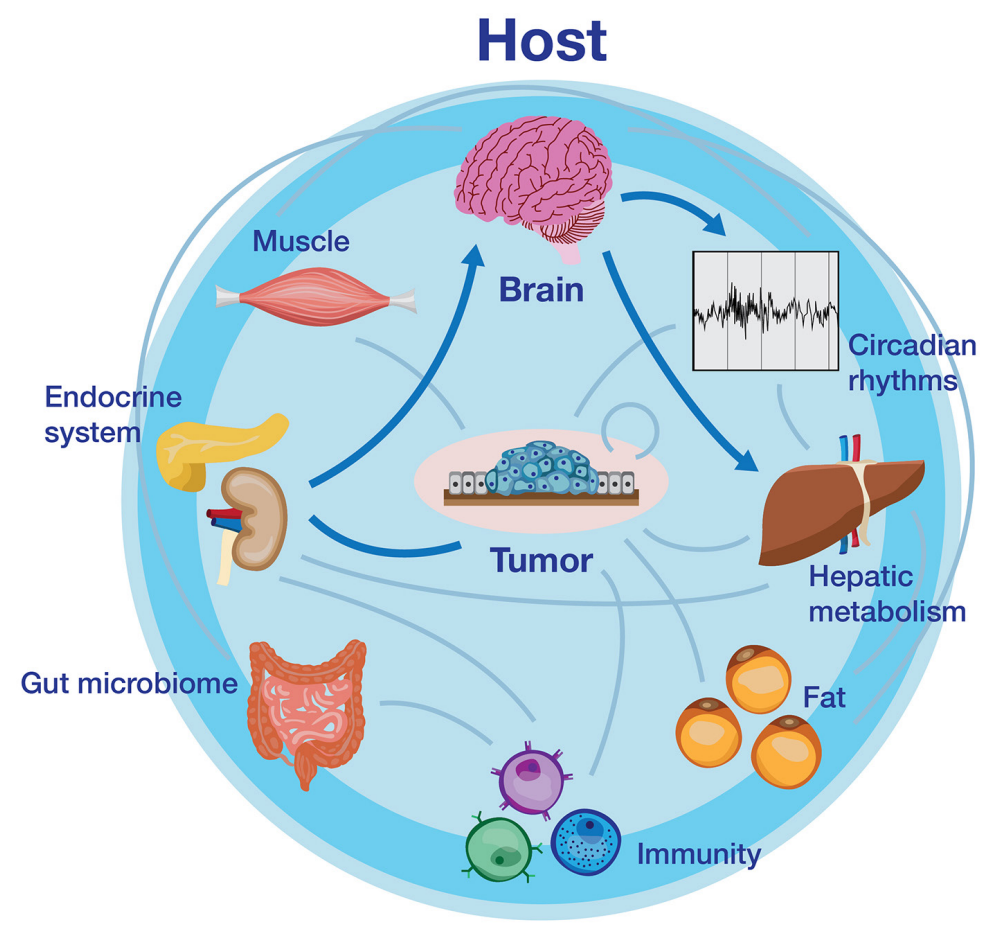

Figure 1. A simplified schematic of reciprocal tumor-host interactions. Tumors promote aberrant physiology via alterations to the immune system and secretion of metabolic "waste" which contributes to further inflammation and altered function of distal organs, including the brain. Feedback from the brain (neural or humoral) can subsequently exacerbate tumor-associated immune and metabolic changes, ultimately facilitating tumor growth, angiogenesis, metastasis, or cancer-associated co-morbidities

of poor prognoses and reduced quality of life ${ }^{[1-5]}$. Tumors are capable of altering local macronutrient contents that modulate infiltrating immune cell function resulting in aberrant inflammation. Additionally, they secrete metabolic "waste", which can promote inflammation and alter the function of distal organs and tissues such as the liver and brain ${ }^{[6-10]}$. As evidence accumulates, we are learning that many of these cancer-associated co-morbidities are (at least in part) due to deregulation of normal brain function by the cancer itself, cancer treatment(s), or other factors.

Reciprocally, the host system can influence tumor growth and metastasis via immune, endocrine, and neural pathways. For example, chronic stress, which results in dysregulation of glucocorticoid and adrenergic signaling, exacerbates tumor growth and angiogenesis ${ }^{[1,12]}$. Additionally, chronic sleep fragmentation, resulting in top-down impairments to the immune system, further promotes tumor growth ${ }^{[13]}$. The objective of this review is to provide an up-to-date overview of cancer as a systemic disease from a basic science perspective [Figure 1]. Special focus will be given to subcortical neural populations that are sensitive to signals arriving from peripheral tissues and the environment, as well as those that send long-range projections to modulate immune or metabolic function, ultimately facilitating cancer growth and/or metastasis. Through understanding these brain-tumor interactions, potential undescribed drug or lifestyle targets will be uncovered. Additionally, these studies would open up space for existing therapies to be repurposed for effective cancer treatment (as is the case with the anti-obesity drug Metformin ${ }^{[14,15]}$.

\section{NEURAL CIRCUITRY DEREGULATED IN CANCER}

\section{Sleep disruption}

Disruption of sleep and/or circadian rhythms in physiology and behavior are frequently observed in cancer patients. Indeed, $35 \%-80 \%$ of cancer patients report poor sleep quality ${ }^{[16,17]}$, as compared to $29 \%-32 \%$ of the general population ${ }^{[18]}$ [Table 1]. These problems may stem from the cancer itself, the stress or stigma 
Table 1. Non-exhaustive list of clinical observations of systemic co-morbidities potentially influencing brain function (sleep disturbance, circadian rhythm disruption, cognitive impairment, metabolic abnormalities, microbial dysbiosis, and systemic inflammation) in patients with cancer

\begin{tabular}{|c|c|c|c|c|}
\hline $\begin{array}{l}\text { Systemic } \\
\text { problem }\end{array}$ & Patient population & Methods & Primary observation & Ref. \\
\hline \multirow[t]{2}{*}{$\begin{array}{l}\text { Sleep } \\
\text { disturbance }\end{array}$} & $\begin{array}{l}823 \text { patients with cancer } \\
\text { receiving chemotherapy }\end{array}$ & $\begin{array}{l}\text { Post-hoc analysis of data from } \\
\text { a large randomized clinical trial; } \\
\text { Hamilton Depression Inventory } \\
\text { used to assess sleep disturbance }\end{array}$ & $\begin{array}{l}36.6 \%(n=301) \text { of the patients with } \\
\text { cancer reported insomnia symptoms, and } \\
43 \%(n=362) \text { met the diagnostic criteria } \\
\text { for insomnia syndrome; breast cancer had } \\
\text { the highest number of overall insomnia } \\
\text { complaints }\end{array}$ & [120] \\
\hline & $\begin{array}{l}85 \text { women with Stages I-IIIA } \\
\text { breast cancer }\end{array}$ & $\begin{array}{l}\text { actigraphy for } 72 \text { consecutive } \\
\text { hours and filled out } \\
\text { questionnaires (PSQI, MFSI-SF, }\end{array}$ & $\begin{array}{l}\text { women slept for } \sim 6 \text { h a night and napped }> \\
1 \text { h during the day. Sleep was disturbed and } \\
\text { fatigue levels were high; phase-delayed }\end{array}$ & [121] \\
\hline
\end{tabular}

97 women with advanced breast cancer (age $=54.6 \pm$ 9.8 years)
FOSQ, FACT-B, and CES-D) on sleep, fatigue, depression, and functional outcome

$72 \mathrm{~h}$ actigraphy; sleep efficiency was determined as the ratio of total sleep time to total sleep time plus wake after sleep onset

40 patients ( 50 years, SD = $11 ; 53 \%$ White, 28\% Asian, $19 \%$ Other) with primary breast cancer (18\% Stage I, 50\% Stage II, 33\% Stage III) undergoing chemotherapy

389 Caucasian cases and

Circadian rhythm disruption
Neurocognitive battery of tests including PSQI, ISI, BFI, CAD, COWAT, HVLT; actigraphy for 7 consecutive days to track arousal/sleep
432 Caucasian controls

57 presurgical breast cancer patients

104 patients with metastatic breast cancer

43 breast cancer patients
Investigated the association between an exonic length variation in a circadian gene, Period3 (Per3), and breast cancer risk using blood samples collected from a recently completed breast cancer casecontrol study in Connecticut Daily self-reports of cancerspecific distress and avoidant coping as well as actigraphic and salivary cortisol data

Salivary cortisol levels assessed at study entry at 800, 1200, 1700, and 2100 hours on each of 3 consecutive days; NK cells measured using flow cytometry, activity by chromium release assay

Actigraphy, cancer-specific distress (IES, POMS), saliva samples for assessment of diurnal cortisol rhythm, cortisol awakening response (CAR), and diurnal mean. Ten potential markers of tumor progression were quantified in serum and grouped by exploratory factor analysis
Sleep efficiency predicted reduction in overall mortality [hazard ratio (HR), $0.96 ; 95 \%$ confidence interval $(\mathrm{Cl}), 0.94$ $0.98 ; P<0.001$ ] at median 6 y follow-up. Remained significant (HR, 0.94; $95 \% \mathrm{Cl}$, $0.91-0.97 ; P<0.001)$ after adjusting for age, estrogen receptor status, cancer treatment, metastatic spread, cortisol levels, and depression Better circadian function was associated with less sleep disruption (PSQI, $r=-0.44$, $P=0.005)$ and less insomnia (ISI, $r=$ $-0.42, P=0.008)$. Both subjective sleep alteration and circadian disruption were associated with levels of fatigue (BFI, all $P$-values $<0.05)$ and sleep disruption measures were strongly associated with depression and anxiety

(ISI: $r=0.51, P=0.001$; PSQI: $r=0.43, P=$ 0.005)

Per3 genotype (heterozygous +

homozygous 5-repeat alleles) was associated with an increased risk of breast cancer among premenopausal women (odds ratio, $1.7 ; 95 \% \mathrm{Cl}, 1.0-3.0$ )

Distress and avoidant coping were related to rest/activity rhythm disruption (daytime sedentariness, inconsistent rhythms). Patients with disrupted rest/activity cycles had flattened diurnal cortisol rhythms Cortisol slope predicted survival up to 7 years later. Earlier mortality occurred among patients with relatively "flat" rhythms, indicating a lack of normal diurnal variation (Cox proportional hazards, $P=$ 0.0036); associated with low counts and suppressed activity of NK cells Poor circadian coordination as measured by rest-activity rhythms had higher factor 1 (MMP9, TGF-beta, VEGF) scores $\left(R^{2}=\right.$ $0.160, P=0.038)$. Patients with elevated CAR also had higher Factor 1 scores $\left(R^{2}\right.$ $=0.293, P=0.020)$. These relationships appeared to be driven largely by VEGF concentrations 
Cognitive Impairment

321 patients admitted to the Edmonton General Palliative Care Unit over a period of 26 months

Meta-analysis of 23 studies on cognitive impairment in cancer patients

22 breast cancer survivors who reported cognitive impairment and who were at least 1 year postchemotherapy treatment

85 women with early stage breast cancer scheduled for chemotherapy, 43 women scheduled for endocrine therapy and/or radiotherapy and 49 healthy control subjects

Metabolic Abnormalities
265 patients with advanced breast cancer receiving palliative chemotherapy

Meta-analysis of 20 studies (5 case-control and 15 cohort studies) that reported relative risk (RR) estimates (odds ratio, rate ratio/ hazard ratio, or standardized incidence ratio) with $95 \% \mathrm{Cl}$ for the relation between diabetes (largely Type II diabetes) and breast cancer incidence Pooled individual-level data from 758,592 premenopausal women from 19 prospective cohorts
10,786 women ages $35-$ 69 were recruited in a prospective study in Italy; Four matched controls were chosen for each breast cancer case $(n=144)$
Mini-Mental State Examination (MMSE) was used as screening tool to assess cognitive functioning and was performed on all patients at the time of admission and once to twice weekly thereafter

Articles published 19802012, comparing subjective and objective cognition in cancer patients treated with chemotherapy. Of 818 potentially relevant articles, 23 studies met the inclusion criteria for the current review and one article was sourced from reference lists of included studies Qualitative interviews, recorded, transcribed verbatim, and analyzed using a content analysis approach

3-year prospective study; neuropsychological performance assessed at baseline ( $\mathrm{T} 1$ ), postchemotherapy (or 6 months) (T2) and at 18 months (T3)

Retrospective study; mortality was compared for diabetic and nondiabetic patients as well as for patients that presented hyperglycemia during treatment

RRs were calculated using a random-effects model

\section{Hazard ratios (HRs) of} premenopausal breast cancer in association with BMI from ages 18 through 54 years using Cox proportional hazards regression analysis. Median follow-up; 9.3 years (interquartile range, 4.913.5 years) per participant, with 13,082 incident cases of breast cancer

Blood samples were collected after a 12-h fast between 7:30 and 9:00 a.m.
142 pts (44\%) had abnormal MMSE scores (MMSE < 0.8 ) on admission, whereas 176 patients (55\%) had abnormal MMSE scores at the time of death or discharge; 157 (68\%) had abnormal MMSE scores prior to death; Of 124 patients with normal final MMSE scores, 64 (52\%) were discharged versus 16 of 116 patients (14\%) who had abnormal MMSE final scores $(P<$ 0.0001 )

$8 / 24$ included studies found a significant relationship between objective and subjective measures of cognitive performance. These studies were more likely to involve breast cancer patients and to assess the relationship between memory and perceived cognitive impairment

6 major domains identified: short-term memory, long-term memory, speed of processing, attention and concentration, language and executive functioning; All survivors found these impairments frustrating, and some also reported these changes as detrimental to their selfconfidence and social relationships No significant interactions or main effect of group after controlling for age and intelligence; reliable decline on multiple tasks was seen in $20 \%$ of chemotherapy patients, $26 \%$ of nonchemotherapy patients and $18 \%$ of controls at T2 (18\%, 14 and $11 \%$, respectively, at T3). Those who experienced treatment-induced menopause were more likely to show decline on multiple measures at T2 $(\mathrm{OR}=$ $2.6,95 \% \mathrm{Cl} 0.823-8.266 P=0.086$ ) Overall survival was greater in diabetic patients with proper metabolic control than diabetic patients with hyperglycemia. The risk of death was higher in patients with mean glucose levels $>130 \mathrm{mg} / \mathrm{dL}$ during treatment

All 20 studies showed that women with (vs. without) diabetes had a statistically significant $20 \%$ increased risk of breast cancer (RR, 1.20; 95\% Cl, 1.12-1.28). The summary estimates were similar for casecontrol studies (RR, $1.18 ; 95 \% \mathrm{Cl}, 1.05-1.32$ ) and cohort studies (RR, 1.20; 95\% Cl, 1.111.30)

Inverse linear associations of BMI with breast cancer risk were found that were stronger for $\mathrm{BMI}$ at ages 18 to 24 years (HR per $5 \mathrm{~kg} / \mathrm{m}^{2}$ [5.0-U] difference, 0.77 $95 \% \mathrm{Cl}, 0.73-0.80)$ than for $\mathrm{BMI}$ at ages 45 to 54 years (HR per 5.0-U difference, 0.88; $95 \% \mathrm{Cl}, 0.86-0.91) .4 .2$-fold risk gradient between the highest and lowest BMI categories ( $\mathrm{BMI} \geq 35.0$ vs. < 17.0) at ages 18 to 24 years ( $\mathrm{HR}, 0.24 ; 95 \% \mathrm{Cl}$, 0.14-0.40)

Adjusted relative risk (RR) for the highest quartile of serum glucose $v s$. the lowest was 2.8 (95\% $\mathrm{Cl}, 1.2-6.5)$, and $P$ for trend was 0.02. Insulin showed a weaker association with breast cancer, the adjusted RR of the highest quartile $v s$. the lowest was $1.7(95 \% \mathrm{Cl}, 0.7-4.1)$, and $\mathrm{P}$ for trend was 0.14 , whereas the adjusted RR of the highest quartile of IGF-I was 3.1 $(95 \% \mathrm{Cl}, 1.1-8.6)$, and $\mathrm{P}$ for trend was 0.01
[125] 
Microbial

Dysbiosis

Breast tumor tissue and paired normal adjacent tissue from the same patient

Qualitative survey of breast microbiota DNA

48 postmenopausal breast cancer case patients, pretreatment, vs. 48 control patients breast cancer

Eighteen patients with breast cancer (BC), 18 with uterine leiomyoma (UL), and 30 healthy women

Systemic Inflammation
Data from the Health, Eating, Activity, and Lifestyle (HEAL) Study (a multiethnic prospective cohort study of women diagnosed with stage 0 to IIIA breast cancer) (734 total survivors)

96 patients with metastatic breast cancer. During followup 51 patients died of their cancer

Colorectal $(n=182)$, gastric ( $n=87)$, breast $(n=99)$, or bronchogenic $(n=404)$ cancer patients, who had measurements of $\mathrm{C}$-reactive protein and albumin
Microbiota profiles in fecal DNA were determined by Illumina sequencing and taxonomy of $16 \mathrm{~S}$ rRNA genes. Estrogens were quantified in urine; linear and unconditional logistic regression of microbiota $\alpha$-diversity (PD_ whole tree) and UniFrac analysis of $\beta$-diversity

Bacterial DNA was extracted from the feces; GPCR amplified, targeting 16S rRNA sequences specific to bacterial groups, and then analyzed in relation to clinical characteristics

Feces were collected on 1st admission and processed immediately; qualitative and quantitative analysis of fecal flora

Concentrations of CRP and SAA were measured approximately 31 months after diagnosis and tested for associations with diseasefree survival (approximately 4.1 years of follow-up) and overall survival (approximately 6.9 years of follow-up)

Evaluated the value of an inflammation-based score (Glasgow Prognostic Score, GPS) in patients with metastatic breast cancer (scored on 0-2 scale) Median survival, univariate/ multivariate analyses of correlations between inflammatory markers and survival

Metabolic syndrome-associated circulating factors were compared by CLS-B status. The association between CLS of the breast and the metabolic syndrome was validated; Distant recurrence-free survival (dRFS) was compared by CLS-B status
Bacterium Methylobacterium radiotolerans is relatively enriched in tumor tissue, while the bacterium Sphingomonas yanoikuyae is relatively enriched in paired normal tissue. The relative abundances of these two bacterial species were inversely correlated in paired normal breast tissue but not in tumor tissue, indicating that dysbiosis is associated with breast cancer Estrogens correlated with $\alpha$-diversity in control patients (Spearman Rho $=0.37, P$ $=0.009$ ) but not case patients (Spearman Rho $=0.04, P=0.77$ ). Compared with control patients, case patients had statistically significantly altered microbiota composition ( $\beta$-diversity, $P=0.006$ ) and lower $\alpha$-diversity $(P=0.004)$. Adjusted for estrogens and other covariates, odds ratio of cancer was $0.50(95 \% \mathrm{Cl}, 0.30$ $0.85)$ per $\alpha$-diversity tertile Absolute numbers of total bacteria and three bacterial groups (Firmicutes, Faecalibacterium prausnitzii, and Blautia) differed significantly according to the patient's body mass index. C. coccoides, F. prausnitzii, and Blautia, differed significantly according to the clinical stages and the histoprognostic grades Premenopausal BC patients showed increased Enterobacteriaceae (E. coli, log $9.7 \pm 2.1, P<0.001)$; aerobic streptococci $(\log 7.8 \pm 2.0)$ and lactobacilli $(\log 8.0 \pm$ 2.8). Anaerobic bacteria were increased $(P<0.001)$ for clostridia $(\log 9 \pm 1.7)$, bacteroides ( $\log 7.2 \pm 3.1)$, and anaeroboic lactobacilli ( $9.1 \pm 2.5)$. Similar changes in menopausal samples

Elevated SAA and CRP were associated with reduced overall survival, regardless of adjustment for age, tumor stage, race, and body mass index (SAA $P$ trend $<0.0001$; CRP $P$ trend $=0.002$ ). The HRs for SAA and CRP tertiles suggested a threshold effect on survival, rather than a doseresponse relationship (highest $v s$. lowest tertile: SAA HR = 3.15; $95 \% \mathrm{Cl}, 1.73-5.65$; CRP HR $=2.27: 95 \% \mathrm{Cl}, 1.27-4.08$ ) Multivariate analysis of the GPS and treatment received, only the GPS (HR 2.26 $95 \% \mathrm{Cl} 1.45-3.52, P<0.001)$ remained significantly associated with cancerspecific survival

Association between duration of survival and both $\log _{10} \mathrm{C}$-reactive protein and albumin concentrations $(P<0.0002) . \log _{10}$ $C$-reactive protein was an independent predictor of survival $(P<0.0002)$. When all patients were analyzed $(n=772)$ the hazard ratio for a 10 -fold increase in $\mathrm{C}$-reactive protein concentration in cancerspecific survival was $2.21(95 \% \mathrm{Cl}=1.92$ 2.56, $P<0.0001)$

Pts with WAT inflammation had elevated insulin, glucose, leptin, triglycerides, C-reactive protein, and IL6 and lower high-density lipoprotein cholesterol and adiponectin $(P<0.05)$; Compared with patients without breast WAT inflammation, the adjusted $\mathrm{HR}$ for dRFS was $1.83(95 \% \mathrm{Cl}$, 1.07-3.13) for patients with inflammation
[133] undergoing mastectomy for breast cancer risk reduction $(n=10)$ or treatment $(n=$ 90). Retro study was 127 women who developed metastatic breast cancer 
surrounding a cancer diagnosis, different treatment regimens (e.g., chemotherapy, immunotherapy and/ or radiotherapy), or additional lifestyle factors ${ }^{[19]}$. These problems are prevalent across a variety of cancer types, with lung and breast cancer patients making up the majority of the population experiencing these symptoms ${ }^{[2,20-22]}$. A "chicken-or-the-egg" phenomenon has emerged: poor sleep associates with elevated cancer incidence and progression, and cancer and/or cancer treatments further promote sleep disturbance ${ }^{[2,3,6,23]}$. Due to the heterogeneity among cancer types, patient populations, treatment regimens, and lifestyle factors, it has been challenging to pin down cause and effect. This lack of knowledge prevents targeted therapies from being developed and impairs quality of life and lifespan in cancer survivors. For example, sleep disruption is associated with increased mortality in breast cancer independent of other factors like estrogen receptor status, depression, anxiety, and socioeconomic status ${ }^{[3]}$.

The hypothalamus is a critical structure for maintaining homeostasis ${ }^{[24,25]}$. Although beyond the scope of this review, a brief discussion of its relevant circuitry is warranted to put the rest of our discussion in context. Its functions include the regulation of sleep-wake cycles, circadian rhythms, body temperature, feeding/metabolism, the stress response, and reproduction, among others. Many of these are linked to either the promotion of cancer development or it's progression (as I discuss in subsequent sections). The lateral hypothalamus (LH) is a highly heterogeneous structure that serves a primary role in arousal, metabolism, and motivated behavior ${ }^{[24]}$. A neural population that has been intensely studied in this area are those that express the excitatory neuromodulators hypocretin-1 and hypocretin-2 (aka orexin-A and - $\mathrm{B} ; \mathrm{HO}$ ) ${ }^{[26,27]}$. Discovered by two groups at essentially the same time ${ }^{[28,29]}$, these neurons are critical for maintaining wakefulness, as their destruction results in the sleep disorder narcolepsy ${ }^{[30-33]}$.

HO neurons project throughout the brain to participate in functions ranging from arousal and motivation, to anxiety and reproductive behavior ${ }^{[27]}$. Importantly, they also send long range projections that modulate sympathetic outflow from the brain ${ }^{[34]}$. Indeed, disinhibition of HO neurons in the LH can directly influence hepatic gluconeogenesis, promoting de novo glucose production upon stimulation ${ }^{[35]}$. Reciprocally, HO neurons are sensitive to metabolic signals arriving from the periphery. These include hormones and other messages important in cancer regulation, including leptin, ghrelin, glucose, dietary amino acids, and changes in extracellular $\mathrm{pH}$ and $\mathrm{CO}_{2}$ concentrations ${ }^{[27]}$. Stimulation of $\mathrm{HO}$ neurons further activates the hypothalamicpituitary-adrenal (HPA) axis, resulting in rapid increases in circulating glucocorticoid concentrations ${ }^{[36]}$. Aberrant glucocorticoid rhythms are highly prevalent in breast cancer patients ${ }^{[4]}$, and their actions on the immune system may influence patient prognosis (discussed below).

Leptin, an adipokine hormone that correlates with satiety and body fat accumulation, generally inhibits $\mathrm{HO}$ neurons through direct and indirect pathways ${ }^{[36-38]}$. Specifically, intermingled neurons expressing the long-form leptin receptor (LepRb) provide direct inhibitory input to HO neurons. Overexpression of leptin or it's cognate receptor (Ob-R) in mammary tumors and nearby normal epithelial cells is associated with progressive and metastatic breast cancer ${ }^{[39,40]}$. In this way, leptin overexpression may be relevant to fatigue and sleep disruption in cancer patients, through its inhibitory actions on $\mathrm{HO}$ neurons. Ghrelin, an orexigenic hormone produced primarily in the stomach ${ }^{[41-43]}$ has an excitatory effect on $\mathrm{HO}$ neurons, and inhibition of HO neural activity can prevent ghrelin-induced feeding behavior ${ }^{[4,45]}$. Ghrelin or the activity of its catalytic enzyme ghrelin-O-acyl-transferase is frequently deregulated in cancer ${ }^{[46-48]}$, where it associates with cancerinduced cachexia. The role these and other metabolic factors play in cancer and cancer-related co-morbidities is coming into focus as the research community begins to examine them in addition to long-standing candidates from the immune system such as cytokines [e.g., interleukin (IL)-1 $\beta$, IL-6, TNF- $\alpha$ ] and chemokines (e.g., CCL2, CXCL12).

Indeed, brain-tumor-metabolic interactions were recently tested in a mouse model of non-metastatic breast cancer $^{[6]}$. Borniger, Walker and colleagues examined sleep and whole-body metabolic changes during the 


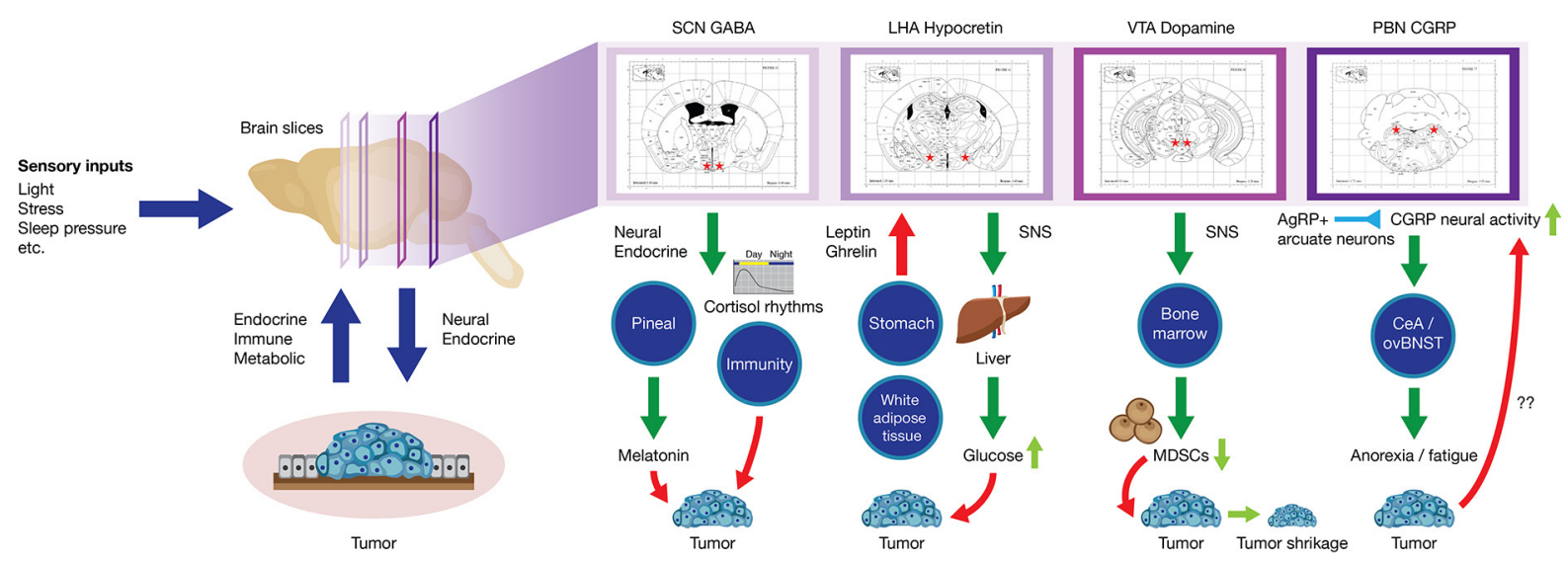

Figure 2. Highlighted pathways linking the brain and periphery in the context of cancer. Environmental (e.g., light, stress) or endogenous signals reach the brain to alter the activity of neurons involved in sleep (LHA hypocretin/orexin), circadian rhythms (SCN-GABA), reward (VTA-Dopamine), metabolism, and energy balance (Parabrachial CGRP). Aberrant activity of these cells promotes signaling in the periphery that ultimately facilitates tumor growth, angiogenesis, and invasiveness. Systems highlighted are bolded in Table 2. LHA: lateral hypothalamic area; SCN: suprachiasmatic nucleus; GABA: gamma amino butyric acid; VTA: ventral tegmental area; PBN: parabrachial nucleus; CGRP: calcitonin gene related peptide; MDSCs: myeloid derived suppressor cells; SNS: sympathetic nervous system; AgRP: agouti related peptide

course of tumor progression. They observed marked peripheral inflammation driven by the cytokine IL-6. This was associated with a shift towards hepatic gluconeogenesis over glycolysis in tandem with disrupted sleep [Figure 2]. Additionally, tumor-bearing mice had reduced circulating leptin concentrations and were hypersensitive to the orexigenic hormone ghrelin. As $\mathrm{HO}$ neurons are sensitive to these peripheral metabolic signals, and they are powerful regulators of wakefulness, the authors examined whether their activity was modulated by tumor growth. They noted that tumors promoted aberrant activity within HO neurons, and inhibition of their signaling (via administration of a dual HO receptor antagonist) attenuated both metabolic and sleep problems. The authors reasoned that in order for $\mathrm{HO}$ neurons to influence peripheral glucose metabolism, a signal must reach the liver from the brain. A potential pathway through which this could occur is the sympathetic nervous system (SNS) ${ }^{[35]}$. Ablating the SNS with administration of 6-hydroxydopamine (6OHDA) rescued tumor-induced metabolic deficits, supporting the idea that $\mathrm{HO}$ neurons modulate peripheral glucose concentrations via downstream SNS activation ${ }^{[6]}$. Significantly more research is required to unravel the complex signaling network linking tumors in the periphery to changes in the activity of this critical neural population. However, these findings suggest that repurposing drugs targeting this system [e.g., Suvorexant $\left(\right.$ Belsomra $\left.{ }^{\circledR}\right)$ may be a novel strategy for improving sleep and metabolic health in patients with cancer.

In two mouse models of lung cancer (LLC and TC1), Hakim et al. ${ }^{[13]}$ demonstrated that chronic sleep fragmentation promoted tumor growth, a phenotype that was abolished in mice lacking the endotoxin receptor TLR4. TLR4 is part of a family of pattern recognition receptors that powerfully engage the innate immune system upon ligand binding. Surprisingly, the effect of sleep fragmentation on tumor progression was maintained in mice lacking TLR4 effector molecules MyD88 or TRIF, although the effect was reduced. This was the first study to causally link disrupted sleep, tumor progression, and immune deregulation. Although this approach lacks cell-type specific investigations into neural populations influenced by the sleep fragmentation protocol, it suggests one or more neural populations sensitive to this manipulation may be responsible for top-down changes to the immune system that biases the host environment to one that favors tumor growth. Recently, McAlpine et al ${ }^{[49]}$ demonstrated one such pathway, where sleep disruption decreased the number of HO-expressing neurons. This led to aberrant regulation of pre-neutrophils in the bone marrow, which were found to express $\mathrm{HO}$ receptor 1 . This change in activity promoted egress of myeloid lineage cells, which then contributed to the development of atherosclerosis. I speculate that a similar phenomenon occurs in the context of cancer ${ }^{[49]}$. The studies discussed in this section highlight the bidirectional pathway between 
sleep and cancer, where disrupted arousal influences cancer growth and aberrant neoplasia reciprocally promotes changes in sleep.

\section{Circadian deregulation}

The paired suprachiasmatic nuclei (SCN) are the primary structures responsible for setting circadian rhythms in physiology and behavior that we observe across most of the phylogenetic tree ${ }^{[50-53]}$. The SCN receive photic input from specialized retinal ganglion cells that serve a minimal role in vision. These cells express a photosensitive protein, melanopsin, allowing them to directly sense light, and are therefore named "intrinsically photosensitive retinal ganglion cells" (ipRGCs) ${ }^{[54,55]}$. ipRGCs transduce photic input into a neurochemical one, with axons traversing the retino-hypothalamic tract and terminating in the suprachiasmatic nucleus. Here, glutamate-mediated synaptic transmission results in downstream cyclic adenosine monophosphate (cAMP) accumulation and cAMP response element binding (CREB) phosphorylation. Phosphorylation of CREB results in it binding the promoters of the core clock genes per and cry. In a transcription-translation loop, the protein products homo or heterodimerize (e.g., PER::CRY dimers), enter the nucleus, and suppress the transcription of the positive arms of the circadian clock, the genes arntl1 (bmal1) and clock.

This process takes approximately $24 \mathrm{~h}$ to complete, where light-induced gene transcription has a phasemodulatory effect on the clock. This feedback loop operates in a cell-autonomous manner throughout the body, with peripheral clocks "set" via neural and humoral routes originating from the SCN ${ }^{[56,57]}$. Behavioral and physiological outputs controlled by the clock include sleep-wake cycles, appetite and food intake, mating and reproductive behavior, rhythms in immune function and glucocorticoid secretion, and stress responses, among others.

Chronic circadian disruption (e.g., via aberrant light exposure, genetic manipulations, or phase shifting) is repeatedly associated with spontaneous cancer occurrence in humans and multiple rodent models spanning a variety of cancer types ${ }^{[2,4,21,58,59]}$. For example, chronic circadian disruption via repeated inversions of the light-dark cycle promotes spontaneous tumor development in a mouse model of breast cancer mimicking LiFraumeni syndrome ${ }^{[60]}$. This paradigm is known to cause significant disruption of the circadian clock as well as the sleep-wake cycle. Using a transgenic approach to specifically knockdown the tumor-suppressor p53 in mammary epithelial cells (WAP-Cre:: $553^{\mathrm{fl} / \mathrm{f}}$ ), van Dycke and colleagues demonstrated that mice undergoing the inversion protocol developed mammary tumors $\sim 8$ weeks sooner (median; 17\% sooner) than their control counterparts. This was accompanied by increased body mass gain in mice experiencing circadian disruption, as well as gross increases in sleep throughout the experiment. This was the first study to demonstrate a causal role for light-induced circadian disruption in the acceleration of spontaneous breast cancer development.

In a similar study, Papagiannakopoulos and colleagues investigated the effects of environmental and genetic circadian disruption on lung tumorigenesis ${ }^{[61]}$. Using a cre-inducible model of lung cancer

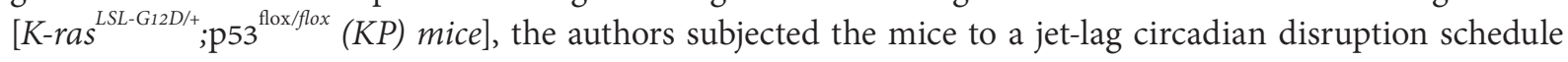
and examined tumor growth, metabolism, and proliferative capacity. Chronic jet-lag accelerated tumor growth, severity, and mortality upon cre-mediated recombination. A similar phenotype was uncovered when manipulations consisted of knocking out core clock genes (Per2 or Bmal1 (Arntli)) in animals that develop spontaneous cancer ( $\mathrm{Kras}^{\mathrm{LA2} / \mathrm{t}}$ mice). Tumor cells deficient in per2 were also more proliferative in culture, and mouse embryonic fibroblasts lacking kras and per2 were more sensitive to cellular transformation than their Per2-intact counterparts. As energy balance is powerfully regulated by circadian rhythms, they investigated cellular metabolic pathways in Per2 deficient cells. Indeed, cells lacking this core clock gene showed a marked increase in the excretion of core energy substrates lactate, glucose, and glutamine, indicating a systemic effect of circadian disruption. Using isotope labeled glucose (U-13Cglucose) and carbon 4 (M4) labeling they demonstrated that cells with disrupted circadian clocks increased the amount of glucose loaded into the tricarboxylic acid cycle, a finding that agreed with prior reports ${ }^{[62]}$. Finally, they investigated whether clock 
gene abnormalities were found in primary patient tumors and noted that all genes (except for clock) were down-regulated in lung cancer samples.

In a reciprocal set of experiments to those discussed above, Masri \& colleagues investigated how tumors themselves disrupt host circadian rhythms, independent of the outside environment ${ }^{[10]}$. In a mouse model of lung adenocarcinoma, they demonstrated that tumors dysregulated the circadian expression of genes controlling immunity and metabolism in a distal organ, the liver, without affecting core components of the circadian clock. This was subsequently confirmed in an additional model of non-metastatic breast cancer, as discussed above ${ }^{[6]}$. These changes were hypothesized to be due (in part) to tumor-induced IL- 6 signaling interfering with insulin-dependent glucose uptake via a SOCS3-regulated mechanism. Experiments like those discussed above highlight the bidirectional cross-talk among the circadian system (ultimately controlled by the brain), tumors, and the host. These findings suggest that novel approaches for cancer treatment lie in the normalization of circadian rhythms via light, nutrition, or clock phase or amplitude-modulating compounds. Indeed, a flavonoid found in citrus peel, nobiletin, is a powerful clock-enhancing molecule ${ }^{[63]}$ that shows promise in the treatment of a variety of cancers ${ }^{[64-66]}$.

\section{Melatonin}

Melatonin is an indoleamine hormone produced and secreted into circulation primarily by the pineal gland in mammals, where it acts as an endogenous signal of darkness ${ }^{[56,67-70]}$. Through a poly-synaptic pathway, the suprachiasmatic nuclei control melatonin production and secretion, rendering the concentrations of this hormone sensitive to environmental light input ${ }^{[71]}$. Because light activates the SCN to cause downstream inhibition of the pineal gland, darkness induced disinhibition permits melatonin secretion only during the night.

Melatonin is a pleiotropic immunomodulatory molecule. Broadly, melatonin is immune-enhancing, acting as a mild anti-inflammatory agent, buffering the immune system against glucocorticoids and reactive oxidative and nitrosative stress ${ }^{[72-74]}$. Shift work and transmeridian travel, two behaviors that strongly alter melatonin rhythms, are associated with cancer incidence. In 2007, the International Agency for Research on Cancer classified shift work with circadian disruption or chronodisruption as a probable human carcinogen ${ }^{[75]}$. Artificial light at night (e.g., street and house lights), which inhibits pineal melatonin, is associated with increased breast cancer prevalence ${ }^{[22,76,77]}$, although the findings are not universally consistent ${ }^{[78]}$. The mechanisms behind these trends are becoming clearer thanks to basic research.

In a clever experimental design, Blask \& colleagues investigated the role of melatonin on human breast cancer xenograft tumor progression in nude rats ${ }^{[79]}$. Blood samples were collected from healthy female volunteers during the day, night, or after 90 min exposure to bright white light at night (to putatively knockdown circulating melatonin concentrations). Melatonin deficient- (daytime or light at night collected) or sufficient blood were then perfused into the tumor xenografts. Tumors perfused with daytime or light at night-exposed blood samples showed high proliferative activity and linoleic acid uptake/metabolism, while those perfused with melatonin-rich nocturnal blood had markedly reduced proliferative activity. Additionally, exposing tumor-bearing rats to increasing intensities of artificial light dose-dependently accelerated tumor growth in tandem with knockdown of circulating melatonin. These results were the first to suggest that light at night exerts its pro-tumorigenic effects via its actions on circulating melatonin concentrations ${ }^{[79]}$. Since the publication of this study, melatonin has been intensely investigated as an anticancer molecule, particularly in the context of breast cancer ${ }^{[00,81]}$. Potential mechanisms for its actions have been uncovered, including antiestrogen, angiogenic, and oxidant pathways ${ }^{[82]}$. As an ancient and pleiotropic hormone, melatonin is not the "cleanest" anti-cancer molecule, given its distributed effects on many tissues throughout the body. However, understanding the mechanisms by which it exerts its anti-cancer effects will likely lead to novel and targeted 
treatments ${ }^{[83]}$. Additionally, due to its low toxicity and high tolerability, it may be useful as a powerful and inexpensive adjunct therapy.

\section{Midbrain reward system}

The midbrain ventral tegmental area (VTA) and neighboring substantia nigra are the primary source of all dopamine (DA) within the brain. Known for its important role in reward and motivational processing (i.e., calculating reward-prediction errors), the VTA has recently become a target for modulating cancer. Elevated concentrations of dopamine are associated with blunted tumor growth, reduced angiogenesis, and lower metastatic capacity of cancer in rats ${ }^{[8]}$. In general, dopamine seems to inhibit cancer growth, while serotonin facilitates $i^{[85]}$. The mechanisms underlying this phenomenon are unclear, although research has started to make headway in this area. In recent years, the VTA has been linked to the modulation of both innate and adaptive immunity ${ }^{[86]}$. Using designer receptors exclusively activated by designer drugs (DREADDs), Rolls and colleagues demonstrated that activation of VTA-DA neurons promotes monocyte/macrophage expansion and innate immune responses to E. coli infection. Activation of these neurons further increased the number of circulating B-cells, subsequent $\operatorname{IgM}$ and $\operatorname{IgG}$ titers in response to E. coli, and interferon-g production by T-cells, suggesting enhanced adaptive immunity.

After these initial studies, they applied their findings to a mouse model of lung cancer ${ }^{[87]}$. After injecting viruses encoding Gq-coupled DREADDs into the VTA (as previously), mice were injected with subcutaneous tumor cells (LLC or B16 cancer cells), and then given daily injections of the DREADD ligand CNO, chronically activating the VTA. Mice that were "VTA-activated" developed smaller tumors than control mice that did not express the DREADD in the VTA [Figure 2]. To examine how this signal from the brain might reach the tumor, the authors ablated the sympathetic nervous system using the neurotoxin 6-hydroxydopamine (6OHDA; as discussed earlier). Mice that were SNS-ablated (or received a beta-adrenergic receptor antagonist) failed to reduce their tumor burden upon VTA-DA activation. They further showed that VTA activation altered norepinephrine concentrations specifically in the bone marrow, a vital immune compartment. This strongly supports the hypothesis that VTA-DA neurons alter tumor growth via SNS innervation of the bone marrow. As myeloid derived suppressor cells (MDSCs) express beta-2 adrenergic receptors and regulate tumor growth via inhibition of anti-tumor immunity, the authors examined their phenotype in response to VTA activation. DREADD-induced VTA activation reduced the number of MDSCs, suggesting that the actions of central VTA stimulation on tumor growth may be through sympathetic suppression of MDSCs. To test the role these cells played in their model, they adoptively transferred MDSCs from VTA-activated mice to control mice not expressing the Gq-coupled DREADD in the VTA. This recapitulated the anti-tumor effect of VTAactivation. This suggests that modulation of the immune system via a discrete population of neurons within the brain acts (at least in part) to suppress tumor growth via the sympathetic nervous system.

\section{Stress - glucocorticoids and catecholamines}

Glucocorticoids (primarily cortisol in humans and corticosterone in mice) are powerfully regulated by circadian rhythms, stress, metabolic state, and immune status ${ }^{[8]}$. Their production and regulation along the HPA-axis has been known for several decades. Their role in linking psychological stress to cancer, however, has only become a subject of intense research within the $21 s t$ century ${ }^{[11]}$. First hinted at in the 70's and 80's, psychological stress has been suspected to influence tumor growth for several decades ${ }^{[89,90]}$. Their role in cancer associated metabolic stress is more well defined. For example, upon metabolic stress induced by cancer-related inflammation (impairments in ketogenesis), glucocorticoids can act to suppress anti-cancer immunity ${ }^{[91]}$. This is associated with disrupted rhythms in glucocorticoid secretion, a component controlled ultimately by a crosstalk between central clocks in the SCN and ancillary oscillators in the adrenal glands ${ }^{[2]}$. Adrenergic signaling, largely driven by activation of the SNS in the context of stress, also has immunomodulatory properties (as discussed above). 
Thaker, Sood \& colleagues provided empirical evidence that psychological stress can facilitate tumor growth in multiple animal models via its promotion of glucocorticoid and adrenergic signaling ${ }^{[12,93]}$. These studies demonstrated that multiple ovarian cancer tumor cell lines (e.g., EG, SKOV3, 222, HeyA8...) enhance invasiveness when exposed to norepinephrine and/or glucocorticoids (in part) via the upregulation of matrix metalloproteinases (MMPs), critical regulators of angiogenesis and tissue remodeling. Blockade of adrenergic signaling or inhibition of MMPs prevented elevations in cell invasiveness. In vivo experiments demonstrated that chronic behavioral stress (restraint) increased tissue catecholamines, tumor growth, vascularization, and invasiveness in an orthotopic mouse model of ovarian cancer. These effects were driven by adrenergic signaling (through the b2-adrenoceptor), resulting in downstream cAMP-protein kinase A (PKA) pathway activation. This subsequently promoted the transcription of vascular endothelial growth factor and the MMPs (-2 and -9$)$. These findings highlight adrenergic-receptor signaling as a potential target for reducing tumor angiogenesis and growth. Indeed, perioperative cyclo-oxygenase 2 and beta-adrenergic blockade was shown to improve measures of metastasis in breast cancer patients, offering a safe and effective adjuvant treatment strategy ${ }^{[94]}$.

\section{Energy balance and feeding}

Disrupted energy balance resulting in enhanced capacity to sustain proliferative growth is a hallmark of cancer $^{[9]}$. Indeed, one of the first major breakthroughs in cancer research was the discovery that tumor cells are biased towards aerobic glycolysis rather than oxidative phosphorylation to produce energy (i.e., the Warburg effect ${ }^{[95-97]}$ ). Therefore, a common finding in malignant cancers is a strong upregulation of lactate and catalytic enzymes required for lactate production from pyruvate (e.g., lactate dehydrogenase) ${ }^{[98-101]}$. Lactate normally acts to aide in glucose sensing and food intake, where it is transported into the brain via monocarboxylate transporters present on endothelial cells lining the blood-brain barrier ${ }^{[102]}$. After entering the brain, lactate is able to interact with neurons that normally promote food intake, such as those that produce agouti-related peptide (AgRP) within the arcuate nucleus. Lactate's mechanism of action on orexigenic cells is via its effects on the adenosine monophosphate kinase/methylmalonyl CoA signaling pathway within the hypothalamus ${ }^{[103]}$. Lactate alone, however, does not seem to be responsible for cancer-associated anorexia (discussed below) $^{[104]}$.

Anorexia is a common phenomenon in cancer patients with weight loss, and even when patients attempt to eat enough to compensate, they frequently cannot maintain a healthy weight. Although significant evidence suggests that inflammatory signaling secondary to tumor growth or cancer-treatment associates with anorexia, a specific neural population and mechanism governing this common problem is lacking ${ }^{[99]}$. An attractive candidate neural population that may underlie these traits (in part) is the calcitonin-gene-relatedpeptide (CGRP) expressing population of cells in the parabrachial nucleus $\left(\mathrm{PBN}_{\mathrm{CGRP}}\right)$. These cells powerfully suppress appetite and promote the termination of feeding behavior ${ }^{[105,106]}$. CGRP neurons are activated by upstream circuits that respond to cancer-associated signals, and are inhibited by those that promote feeding, including hypothalamic AgRP/neuropeptide Y neurons ${ }^{[107]}$. These neurons are also sensitive to peripheral noxious and painful stimuli, which are other aspects of cancer progression ${ }^{[108]}$.

In a mouse model of Lewis lung carcinoma, Schwartz and colleagues investigated how peripheral tumors modulate CGRP neural activity and their role in cancer-associated anorexia/cachexia ${ }^{[109]}$. CGRP neurons were strongly activated in tumor-bearing mice compared with controls, a phenotype typically found after ingestion of a large meal. This suggests that tumors activate cells normally responsible for meal termination and cessation of feeding behavior. Using a cre-dependent tetanus toxin transgene, they demonstrated that inactivation of these cells prevented cancer-associated anorexia/cachexia. Additionally, this manipulation normalized the activity of neurons in circuits downstream from the PBN, namely the central amygdala (CeA) and oval subnucleus of the bed nucleus of the stria terminalis (ovBNST), which may play additional roles in cancer-associated behavioral phenotypes. To control the activity of $\mathrm{PBN}_{\mathrm{CGRP}}$ neurons with better temporal precision, they used Gi-coupled DREADDs to transiently inhibit these neurons in anorexic/cachexic mice. This manipulation was able to recapitulate the effects seen with their previous approach using tetanus toxin. 
Another research area that is rapidly growing in scope is that of brain-gut and gut-cancer interactions. Changes in systemic microbial diversity can influence brain function, alter immune phenotypes, and dictate subsequent cancer development or a tumor's response to immunotherapy ${ }^{[110,111]}$. In a proof-of-principle experiment, Lakritz et al. ${ }^{[112]}$ demonstrated that Helicobacter hepaticus, a pathogenic gut microbe, promotes distal breast tumorigenesis in a neutrophil-dependent manner. Cancer-prone female mice (FVB- $\mathrm{Tg}(\mathrm{C} 3-1-$ $\mathrm{TAg}$ )cJeg/JegJ) were infected with $\mathrm{H}$. hepaticus (via gastric gavage) at 3 months of age, and then assessed for subsequent mammary tumorigenesis. Mice infected with these bacteria developed significantly more tumors than their counterpart controls that were not infected. Additionally, mammary intraepithelial neoplasias were associated with strong neutrophil invasion (myeloperoxidase staining). Chronic depletion of neutrophils (via anti-Ly6-G antibodies) prevented $H$. hepaticus-induced cancer development. These data suggest that hostmicrobe interactions may drive cancer in distal tissues through an immune-mediated mechanism.

\section{CONCLUSIONS AND IMPLICATIONS}

Together, the studies discussed above aim to provide an understanding of the types of inputs the brain receives, the signals it propagates, and the effects of these messages on tumor growth and metastasis. Reciprocally, tumor-induced changes in physiology are relayed to the brain via endocrine, immune, or neural signals that ultimately change the activity of discrete neural populations important for maintaining homeostasis. Resolving the "conflict of interest" between cancer and the brain will undoubtedly lead to improvements in patient quality of life and unlock a novel means for cancer treatment. A summary of these findings from basic science are presented in Table 2.

In this vein, treatments targeting the circadian system (i.e., chronotherapy) have gained significant traction in recent years ${ }^{[113,114]}$. These approaches leverage natural circadian rhythms in metabolism and detoxification systems to schedule chemotherapy or radiotherapy to coincide with times of peak effectiveness with the lowest potential for side-effects. Animal models have further demonstrated that this approach can effectively limit hepatic toxicity and the inflammatory response to chemotherapeutics ${ }^{[115,116]}$. Artificially boosting circadian rhythms (e.g., with nobiletin) adds an additional prospective anti-cancer strategy ${ }^{[64]}$.

Alternatively, targeted stimulation of specific brain areas deregulated in cancer may help overcome resistance to more traditional treatment strategies. As discussed above, stimulation of the dopaminergic ventral tegmental area promotes tumor suppression via the sympathetic nervous system ${ }^{[87]}$. If findings such as these translate to humans, deep brain stimulation protocols could be adapted for adjuvant cancer treatment. For example, deep brain stimulation of the subthalamic nuclei for Parkinson's disease promotes sympathetic activation in a safe and reversible manner ${ }^{[117,118]}$, a procedure that could be repurposed in the context of advanced cancer. Alternatively, biobehavioral therapies can be designed to promote positive thinking and rewarding experiences (to activate the dopaminergic system) to aide in cancer suppression. Indeed, mindfulness meditation has been demonstrated to improve mood, reduce stress, and attenuate inflammation in patients with breast cancer ${ }^{[119]}$.

As cancer drastically alters energy balance, influencing the activity of specific brain nuclei regulating metabolism and food intake (e.g., hypocretin, AgRP, POMC, CGRP neurons) represents a strategy to not only improve quality of life, but limit energy availability to the cancer. Indeed, inhibition of aberrant hypocretin/ orexin signaling promotes sleep and attenuates tumor-induced metabolic abnormalities in a mouse model of breast cancer ${ }^{[6]}$. Repurposing drugs that modify food intake and energy balance (e.g., metformin) further provides additional avenues for adjuvant cancer therapy. However, significant more research is needed to understand both (1) how the brain influences cancer-associated immune populations and (2) how the tumor communicates with the brain to deregulate homeostasis and health. Only then can we begin to manipulate this cross-talk to facilitate cancer elimination. 
Table 2. Non-exhaustive list of primary animal model evidence for brain-tumor interactions regulating cancer incidence, disease progression, morbidity and mortality (see Figure $\mathbf{2}$ for more details)

\begin{tabular}{|c|c|c|c|}
\hline Cancer type/model & Main focus & Primary findings & Ref. \\
\hline $\begin{array}{l}\text { 67NR/4T1/4T07 syngeneic breast } \\
\text { cancer cells (female BalbC mice; } \\
\text { subQ/orthotopic) }\end{array}$ & $\begin{array}{l}\text { Effects of peripheral tumors on central } \\
\text { regulation of sleep and metabolism }\end{array}$ & $\begin{array}{l}\text { Tumors alter leptin/ghrelin signaling, } \\
\text { disrupting central hypocretin/orexin } \\
\text { activity to influence glucose metabolism } \\
\text { and sleep via the sympathetic nervous } \\
\text { system }\end{array}$ & {$[6]$} \\
\hline $\begin{array}{l}\text { LL2 Lewis Lung carcinoma/B6 } \\
\text { (male C57bl6j mice; subQ) }\end{array}$ & Dopaminergic regulation of tumor growth & $\begin{array}{l}\text { Activation of VTA-dopamine neurons } \\
\text { blunts tumor growth via sympathetic } \\
\text { modulation of bone-marrow myeloid } \\
\text { derived suppressor cells }\end{array}$ & [87] \\
\hline $\begin{array}{l}\text { p5 } 53^{\mathrm{R} 270 \mathrm{O} \odot /+} \text { WAP-Cre mutant } \\
\text { model of Li-Fraumeni syndrome } \\
\text { (mouse; transgenic) }\end{array}$ & $\begin{array}{l}\text { Circadian disruption-induced cancer } \\
\text { development }\end{array}$ & $\begin{array}{l}\text { Chronic phase shifting accelerated } \\
\text { spontaneous tumor growth and altered } \\
\text { tumor phenotype }\end{array}$ & {$[60]$} \\
\hline $\begin{array}{l}N \text {-nitroso- } N \text {-methylurea (NMU)- } \\
\text { induced mammary tumors (rat; } \\
\text { chemically induced) }\end{array}$ & Effects of tumors on affective behaviors & $\begin{array}{l}\text { Tumor growth is associated with } \\
\text { central cytokine concentrations, altered } \\
\text { glucocorticoid responses, and the } \\
\text { development of depressive-like behavior }\end{array}$ & [141] \\
\hline $\begin{array}{l}\text { Colon-26 adenocarcinoma cells } \\
\text { (mouse; SubQ) }\end{array}$ & $\begin{array}{l}\text { Effects of tumors on fatigue, muscle } \\
\text { physiology, and affective behaviors }\end{array}$ & $\begin{array}{l}\text { Tumors promoted central } \\
\text { proinflammatory cytokine production and } \\
\text { depressive-like behavior prior to defects } \\
\text { in muscle function, behavior rescued by } \\
\text { SSRI }\end{array}$ & {$[142,143]$} \\
\hline $\begin{array}{l}\text { HeyA8, SKOV3ip1, MB-231 } \\
\text { orthotopic human ovarian } \\
\text { carcinoma cells (nude mice; IP) }\end{array}$ & $\begin{array}{l}\text { Effects of stress on tumor development and } \\
\text { angiogenesis }\end{array}$ & $\begin{array}{l}\text { Stress-induced adrenergic signaling } \\
\text { (cAMP->PKA) promotes tumor growth } \\
\text { and angiogenesis }\end{array}$ & {$[12]$} \\
\hline $\begin{array}{l}\text { Non-metastatic } \\
\text { methylcholanthrene-induced } \\
\text { sarcoma (F344/NTacfBR male } \\
\text { rats; SubQ) }\end{array}$ & $\begin{array}{l}\text { Effects of inflammation on central } \\
\text { hypocretin/orexin neurons and fatigue }\end{array}$ & $\begin{array}{l}\text { Tumors reduced hypocretin/orexin } \\
\text { transcript expression and promoted } \\
\text { fatigue }\end{array}$ & [144] \\
\hline $\begin{array}{l}\text { LL2 or TC-1 lung epithelial cells } \\
\text { (male C } 57 \text { Bl6 mice; subQ) }\end{array}$ & $\begin{array}{l}\text { Role of sleep fragmentation (SF) on tumor } \\
\text { growth and progression }\end{array}$ & $\begin{array}{l}\text { SF accelerates tumor growth, likely } \\
\text { through a TLR4 dependent mechanism }\end{array}$ & [13] \\
\hline $\begin{array}{l}\text { LL2 Lewis Lung carcinoma cells/ } \\
\text { Apc/min+ mice (male and female } \\
\text { C57Bl6; subQ/transgenic) }\end{array}$ & $\begin{array}{l}\text { Role of calcitonin-gene related peptide } \\
(\text { CGRP) neurons in cancer-associated } \\
\text { cachexia }\end{array}$ & $\begin{array}{l}\text { Inactivation of parabrachial CGRP } \\
\text { neurons prevents and reverses cancer- } \\
\text { induced anorexia, fatigue, and changes in } \\
\text { affective behavior }\end{array}$ & {$[109]$} \\
\hline $\begin{array}{l}\text { MADB106 breast cancer cells } \\
\text { (outbred "hyperreactive" Wistar } \\
\text { rats; subQ) }\end{array}$ & $\begin{array}{l}\text { Role of dopaminergic system in tumor } \\
\text { growth/metastasis }\end{array}$ & $\begin{array}{l}\text { Smaller tumors, fewer metastases, and } \\
\text { reduced angiogenesis in rats with a } \\
\text { hyperreactive dopaminergic system }\end{array}$ & {$[84]$} \\
\hline $\begin{array}{l}\text { K-ras } \\
\text { K-ras }{ }^{\text {LSL-G12D/+ }} ; p 53^{\text {flox/flox }}(\mathrm{KP}) \text { or } \\
\text { model } 129 \mathrm{~K}) \text { lung cancer } \\
\text { m C57bl6 mice (cre- } \\
\text { dependent p53 deletion) }\end{array}$ & $\begin{array}{l}\text { Effects of circadian disruption } \\
\text { (environmental and genetic) on lung tumor } \\
\text { growth and progression }\end{array}$ & $\begin{array}{l}\text { Both genetic and physiologic circadian } \\
\text { disruption accelerate tumor growth } \\
\text { and promote c-myc upregulation and } \\
\text { metabolic reprogramming }\end{array}$ & {$[61]$} \\
\hline $\begin{array}{l}\text { diethylnitrosamine-induced } \\
\text { hepatocarcinogenesis (male } \\
\text { Sprague-Dawley rats) }\end{array}$ & $\begin{array}{l}\text { Sympathetic nervous system effect on } \\
\text { hepatocarcinogenesis }\end{array}$ & $\begin{array}{l}\text { High density of SNS bundles associated } \\
\text { with poor prognosis, SNS activation of } \\
\text { Kupffer cells drives inflammation }\end{array}$ & {$[145]$} \\
\hline $\begin{array}{l}\text { Hepatocarcinoma Morris } \\
7288 \text { CTC cells (male buffalo rats) } \\
\text { or steroid receptor (SR)-1+ or SR- } \\
1-\text { MCF-7 human breast cancer } \\
\text { xenografts (female nude rats) }\end{array}$ & $\begin{array}{l}\text { Role of light and melatonin in cancer } \\
\text { progression }\end{array}$ & $\begin{array}{l}\text { Melatonin depleted blood accelerates } \\
\text { tumor growth and metabolism compared } \\
\text { to melatonin-rich blood from healthy } \\
\text { women; light accelerates tumor growth in } \\
\text { dose-dependent manner }\end{array}$ & {$[79]$} \\
\hline $\begin{array}{l}\text { B16 melanoma cells (male nude } \\
\text { mice/C57bl6 } D_{2} \text { receptor-KO) }\end{array}$ & $\begin{array}{l}\text { Role of peripheral dopaminergic signaling in } \\
\text { tumor growth/angiogenesis/metastasis }\end{array}$ & $\begin{array}{l}\text { 6-OHDA ablation of dopaminergic } \\
\text { nerves enhanced tumor angiogenesis } \\
\text { and growth, likely through } \mathrm{D}_{2} \text {-mediated } \\
\text { mechanism }\end{array}$ & [146] \\
\hline $\begin{array}{l}\text { GOS Glasgow osteosarcoma and } \\
\text { pancreatic adenocarcinoma (P03) } \\
\text { xenographs (male B6D2F } F_{1} \text { mice; } \\
\text { subQ into flank) }\end{array}$ & $\begin{array}{l}\text { Effect of suprachiasmatic nucleus lesions on } \\
\text { tumor growth }\end{array}$ & $\begin{array}{l}\text { SCN lesions drastically increased tumor } \\
\text { size in both cancer models examined }\end{array}$ & {$[147]$} \\
\hline $\begin{array}{l}\text { TC-1 mouse lung cancer cells and } \\
\text { human lung adenocarcinoma } \\
\text { cells (male C } 57 \text { bl } 6 \text { mice and } \\
\text { obstructive sleep apnea patients) }\end{array}$ & $\begin{array}{l}\text { Effect of sleep fragmentation on plasma } \\
\text { exosomes and tumor growth }\end{array}$ & $\begin{array}{l}\text { Chronic sleep fragmentation alters the } \\
\text { microRNA cargo of plasma exosomes to } \\
\text { promote tumor cell proliferation }\end{array}$ & {$[148]$} \\
\hline $\begin{array}{l}\text { EG, SKOV3ip1, and } 222 \text { human } \\
\text { ovarian cancer cells (nude male } \\
\text { mice) }\end{array}$ & $\begin{array}{l}\text { Effect of stress hormones on cancer } \\
\text { invasiveness and growth }\end{array}$ & $\begin{array}{l}\text { Adrenergic and glucocorticoid signaling } \\
\text { promotes tumor invasiveness (in part) } \\
\text { via upregulation of MMPs }\end{array}$ & {$[93]$} \\
\hline
\end{tabular}

VTA: ventral tegmental area; cAMP: cyclic adenosine monophosphate; PKA: protein kinase A; 6-OHDA: 6-hydroxydopamine; MMPs: matrix metalloproteinases 


\section{DECLARATIONS}

\section{Acknowledgments}

I thank Drs. Luis de Lecea and Natalie Nevárez for providing critical critiques during the preparation of this manuscript. I thank Dr. Peter Dong for making the illustrations featured in this manuscript. This review was made possible thanks to a BRAIN Initiative NIMH F32MH115431. All efforts were made to include relevant research, failure to do so is the sole responsibility of the author.

\section{Authors' contributions}

Borniger JC contributed solely to this study.

\section{Availability of data and materials}

Not applicable.

\section{Financial support and sponsorship}

This study was supported by NIMH BRAIN Initiative (F32 MH115431).

\section{Conflicts of interest}

The author declared that there are no conflicts of interest.

\section{Ethical approval and consent to participate}

Not applicable.

\section{Consent for publication}

Not applicable.

\section{Copyright}

(c) The Author(s) 2019.

\section{REFERENCES}

1. Bachmann J, Heiligensetzer M, Krakowski-Roosen H, Büchler MW, Friess H, et al. Cachexia worsens prognosis in patients with resectable pancreatic cancer. J Gastrointest Surg 2008;12:1193.

2. Cash E, Sephton SE, Chagpar AB, Spiegel D, Rebholz WN, et al. Circadian disruption and biomarkers of tumor progression in breast cancer patients awaiting surgery. Brain Behav Immun 2015;48:102-14.

3. Palesh O, Aldridge-Gerry A, Zeitzer JM, Koopman C, Neri E, et al. Actigraphy-measured sleep disruption as a predictor of survival among women with advanced breast cancer. Sleep 2014;37:837-42.

4. Sephton SE, Sapolsky RM, Kraemer HC, Spiegel D. Diurnal cortisol rhythm as a predictor of breast cancer survival. J Natl Cancer Inst 2000;92:994-1000.

5. Zhi J, Khozin S, Kuk D, Torres AZ, Sorg R, et al. Association of baseline body mass index (BMI) with overall survival (OS) in patients (pts) with metastatic non-small cell lung cancer (mNSCLC) treated with nivolumab (N) and pembrolizumab (P). J Clin Oncol 2018;36:6553-3.

6. Borniger JC, Walker Ii WH, Surbhi, Emmer KM, Zhang N, et al. A role for hypocretin/orexin in metabolic and sleep abnormalities in a mouse model of non-metastatic breast cancer. Cell Metab 2018;28:118-29.e5.

7. Colegio OR, Chu NQ, Szabo AL, Chu T, Rhebergen AM, et al. Functional polarization of tumour-associated macrophages by tumourderived lactic acid. Nature 2014;513:559-63.

8. Grivennikov SI, Greten FR, Karin M. Immunity, inflammation, and cancer. Cell 2010;140:883-99.

9. Hanahan D, Weinberg RA. Hallmarks of cancer: the next generation. Cell 2011;144:646-74.

10. Masri S, Papagiannakopoulos T, Kinouchi K, Liu Y, Cervantes M, et al. Lung adenocarcinoma distally rewires hepatic circadian homeostasis. Cell 2016;165:896-909.

11. Antoni MH, Lutgendorf SK, Cole SW, Dhabhar FS, Sephton SE, et al. The influence of bio-behavioural factors on tumour biology: pathways and mechanisms. Nat Rev Cancer 2006;6:240-8.

12. Thaker PH, Han LY, Kamat AA, Arevalo JM, Takahashi R, et al. Chronic stress promotes tumor growth and angiogenesis in a mouse model of ovarian carcinoma. Nat Med 2006;12:939-44.

13. Hakim F, Wang Y, Zhang SX, Zheng J, Yolcu ES, et al. Fragmented sleep accelerates tumor growth and progression through recruitment of tumor-associated macrophages and TLR4 signaling. Cancer Res 2014;74:1329-37.

14. Evans JMM, Donnelly LA, Emslie-Smith AM, Alessi DR, Morris AD. Metformin and reduced risk of cancer in diabetic patients. BMJ 2005;330:1304-5. 
15. Hirsch HA, Iliopoulos D, Tsichlis PN, Struhl K. Metformin selectively targets cancer stem cells, and acts together with chemotherapy to block tumor growth and prolong remission. Cancer Res 2009;69:7507-11.

16. Dean GE, Redeker NS, Wang YJ, Rogers AE, Dickerson SS, et al. Sleep, mood, and quality of life in patients receiving treatment for lung cancer. Oncol Nurs Forum 2013;40:441-51.

17. Fortner BV, Stepanski EJ, Wang SC, Kasprowicz S, Durrence HH. Sleep and quality of life in breast cancer patients. J Pain Symptom Manage 2002;24:471-80.

18. Zeitlhofer J, Schmeiser-Rieder A, Tribl G, Rosenberger A, Bolitschek J, et al. Sleep and quality of life in the Austrian population. Acta Neurol Scand 2000;102:249-57.

19. Irwin ML, McTiernan A, Baumgartner RN, Baumgartner KB, Bernstein L, et al. Changes in body fat and weight after a breast cancer diagnosis: influence of demographic, prognostic, and lifestyle factors. J Clin Oncol 2005;23:774-82.

20. Davidson JR, MacLean AW, Brundage MD, Schulze K. Sleep disturbance in cancer patients. Soc Sci Med 2002;54:1309-21.

21. Sephton SE, Lush E, Dedert EA, Floyd AR, Rebholz WN, et al. Diurnal cortisol rhythm as a predictor of lung cancer survival. Brain Behav Immun 2013;30:S163-70.

22. Stevens RG, Brainard GC, Blask DE, Lockley SW, Motta ME. Breast cancer and circadian disruption from electric lighting in the modern world. CA Cancer J Clin 2014;64:207-18.

23. Borniger JC, Gaudier-Diaz MM, Zhang N, Nelson RJ, DeVries AC. Cytotoxic chemotherapy increases sleep and sleep fragmentation in non-tumor-bearing mice. Brain Behav Immun 2015;47:218-27.

24. Bonnavion P, Mickelsen LE, Fujita A, de Lecea L, Jackson AC. Hubs and spokes of the lateral hypothalamus: cell types, circuits and behaviour. J Physiol 2016;594:6443-62.

25. Williams G, Bing C, Cai XJ, Harrold JA, King PJ, et al. The hypothalamus and the control of energy homeostasis: different circuits, different purposes. Physiol Behav 2001;74:683-701.

26. Nevárez N, de Lecea L. Recent advances in understanding the roles of hypocretin/orexin in arousal, affect, and motivation. F1000Res 2018;7:1421.

27. Tyree SM, Borniger JC, de Lecea L. Hypocretin as a Hub for arousal and motivation. Front Neurol 2018;9:413

28. Lecea L de, Kilduff TS, Peyron C, Gao XB, Foye PE, et al. The hypocretins: hypothalamus-specific peptides with neuroexcitatory activity. Proc Natl Acad Sci 1998;95:322-7.

29. Sakurai T, Amemiya A, Ishii M, Matsuzaki I, Chemelli RM, et al. Orexins and orexin receptors: a family of hypothalamic neuropeptides and G protein-coupled receptors that regulate feeding behavior. Cell 1998;92:573-85.

30. Chemelli RM, Willie JT, Sinton CM, Elmquist JK, Scammell T, et al. Narcolepsy in orexin knockout mice: molecular genetics of sleep regulation. Cell 1999;98:437-51.

31. Crocker A, España RA, Papadopoulou M, Saper CB, Faraco J, et al. Concomitant loss of dynorphin, NARP, and orexin in narcolepsy Neurology. 2005;65:1184-8.

32. Hara J, Beuckmann CT, Nambu T, Willie JT, Chemelli RM, et al. Genetic ablation of orexin neurons in mice results in narcolepsy, hypophagia, and obesity. Neuron 2001;30:345-54.

33. Nishino S, Ripley B, Overeem S, Lammers GJ, Mignot E. Hypocretin (orexin) deficiency in human narcolepsy. Lancet 2000;355:39-40.

34. Geerling JC, Mettenleiter TC, Loewy AD. Orexin neurons project to diverse sympathetic outflow systems. Neuroscience 2003;122:541-50.

35. Yi CX, Serlie MJ, Ackermans MT, Foppen E, Buijs RM, et al. A major role for perifornical orexin neurons in the control of glucose metabolism in rats. Diabetes 2009;58:1998-2005.

36. Bonnavion P, Jackson AC, Carter ME, de Lecea L. Antagonistic interplay between hypocretin and leptin in the lateral hypothalamus regulates stress responses. Nat Commun 2015;6:6266.

37. Goforth PB, Leinninger GM, Patterson CM, Satin LS, Myers MG. Leptin acts via lateral hypothalamic area neurotensin neurons to inhibit orexin neurons by multiple GABA-independent mechanisms. J Neurosci 2014;34:11405-15.

38. Håkansson M, De LL, Sutcliffe JG, Yanagisawa M, Meister B. Leptin receptor- and STAT3-immunoreactivities in hypocretin/orexin neurones of the lateral hypothalamus. J Neuroendocrinol 1999;11:653-63.

39. Garofalo C, Koda M, Cascio S, Sulkowska M, Kanczuga-Koda L, et al. Increased expression of leptin and the leptin receptor as a marker of breast cancer progression: possible role of obesity-related stimuli. Clin Cancer Res 2006;12:1447-53.

40. Ishikawa M, Kitayama J, Nagawa H. Enhanced expression of leptin and leptin receptor (OB-R) in human breast cancer. Clin Cancer Res 2004;10:4325-31.

41. Nakazato M, Murakami N, Date Y, Kojima M, Matsuo H, et al. A role for ghrelin in the central regulation of feeding. Nature 2001;409:194-8.

42. Olszewski PK, Li D, Grace MK, Billington CJ, Kotz CM, et al. Neural basis of orexigenic effects of ghrelin acting within lateral hypothalamus. Peptides 2003;24:597-602.

43. Tschöp M, Smiley DL, Heiman ML. Ghrelin induces adiposity in rodents. Nature 2000;407:908-13.

44. García-García F, Juárez-Aguilar E, Santiago-García J, Cardinali DP. Ghrelin and its interactions with growth hormone, leptin and orexins: Implications for the sleep-wake cycle and metabolism. Sleep Med Rev 2014;18:89-97.

45. Toshinai K, Date Y, Murakami N, Shimada M, Mondal MS, et al. Ghrelin-induced food intake is mediated via the orexin pathway. Endocrinology 2003;144:1506-12.

46. Au CC, Furness JB, Brown KA. Ghrelin and breast cancer: emerging roles in obesity, estrogen regulation, and cancer. Front Oncol 2017;6:265.

47. Gahete MD, Córdoba-Chacón J, Hergueta-Redondo M, Martínez-Fuentes AJ, Kineman RD, et al. A novel human ghrelin variant (In1-Ghrelin) and Ghrelin-O-Acyltransferase are overexpressed in breast cancer: potential pathophysiological relevance. PLoS One 2011;6:e23302.

48. Shimizu Y, Nagaya N, Isobe T, Imazu M, Okumura H, et al. Increased plasma ghrelin level in lung cancer cachexia. Clin Cancer Res $2003 ; 9: 774-8$ 
49. McAlpine CS, Kiss MG, Rattik S, He S, Vassalli A, et al. Sleep modulates haematopoiesis and protects against atherosclerosis. Nature 2019;566:383-7.

50. Akhtar RA, Reddy AB, Maywood ES, Clayton JD, King VM, et al. Circadian cycling of the mouse liver transcriptome, as revealed by cDNA microarray, is driven by the suprachiasmatic nucleus. Curr Biol 2002;12:540-50.

51. O'Neill JS, Maywood ES, Chesham JE, Takahashi JS, Hastings MH. cAMP-dependent signaling as a core component of the mammalian circadian pacemaker. Science 2008;320:949-53.

52. Partch CL, Green CB, Takahashi JS. Molecular architecture of the mammalian circadian clock. Trends Cell Biol 2014;24:90-9.

53. Stephan FK, Zucker I. Circadian rhythms in drinking behavior and locomotor activity of rats are eliminated by hypothalamic lesions. Proc Natl Acad Sci U S A 1972;69:1583-6.

54. Baver SB, Pickard GE, Sollars PJ, Pickard GE. Two types of melanopsin retinal ganglion cell differentially innervate the hypothalamic suprachiasmatic nucleus and the olivary pretectal nucleus. Eur J Neurosci 2008;27:1763-70.

55. Hattar S, Liao HW, Takao M, Berson DM, Yau KW. Melanopsin-containing retinal ganglion cells: architecture, projections, and intrinsic photosensitivity. Science 2002;295:1065-70.

56. Borniger JC, Cisse YM, Surbhi, Nelson RJ. Reciprocal regulation of circadian rhythms and immune function. Curr Sleep Med Rep 2017;3:93-103.

57. Scheiermann C, Kunisaki Y, Frenette PS. Circadian control of the immune system. Nat Rev Immunol 2013;13:190-8.

58. Cadenas C, van de Sandt L, Edlund K, Lohr M, Hellwig B, et al. Loss of circadian clock gene expression is associated with tumor progression in breast cancer. Cell Cycle Georget Tex 2014;13:3282-91.

59. Stevens RG. Circadian disruption and breast cancer: from melatonin to clock genes. Epidemiol Camb Mass 2005;16:254-8.

60. Van Dycke KCG, Rodenburg W, van Oostrom CTM, van Kerkhof LWM, Pennings JLA, et al. Chronically alternating light cycles increase breast cancer risk in mice. Curr Biol 2015;25:1932-7.

61. Papagiannakopoulos T, Bauer MR, Davidson SM, Heimann M, Subbaraj L, et al. Circadian rhythm disruption promotes lung tumorigenesis. Cell Metab 2016;24:324-31.

62. Davidson SM, Papagiannakopoulos T, Olenchock BA, Heyman JE, Keibler MA, et al. Environment impacts the metabolic dependencies of ras-driven non-small cell lung cancer. Cell Metab 2016;23:517-28.

63. He B, Nohara K, Park N, Park YS, Guillory B, et al. The small molecule nobiletin targets the molecular oscillator to enhance circadian rhythms and protect against metabolic syndrome. Cell Metab 2016;23:610-21.

64. Chen J, Chen AY, Huang H, Ye X, Rollyson WD, et al. The flavonoid nobiletin inhibits tumor growth and angiogenesis of ovarian cancers via the Akt pathway. Int J Oncol 2015;46:2629-38.

65. Li N, Zhang Z, Jiang G, Sun H, Yu D. Nobiletin sensitizes colorectal cancer cells to oxaliplatin by PI3K/Akt/MTOR pathway. Front Biosci Landmark Ed 2019;24:303-12.

66. Sp N, Kang DY, Joung YH, Park JH, Kim WS, et al. Nobiletin inhibits angiogenesis by regulating Src/FAK/STAT3-mediated signaling through PXN in ER+ breast cancer cells. Int J Mol Sci 2017;18:E935.

67. Bedrosian TA, Herring KL, Walton JC, Fonken LK, Weil ZM, et al. Evidence for feedback control of pineal melatonin secretion. Neurosci Lett 2013;542:123-5.

68. Borniger JC, Nelson RJ. Photoperiodic regulation of behavior: peromyscus as a model system. Semin Cell Dev Biol 2017;61:82-91.

69. Hardeland R, Poeggeler B. Non-vertebrate melatonin. J Pineal Res 2003;34:233-41.

70. Tan DX, Hardeland R, Manchester LC, Paredes SD, Korkmaz A, et al. The changing biological roles of melatonin during evolution: from an antioxidant to signals of darkness, sexual selection and fitness. Biol Rev 2010;85:607-23.

71. Teclemariam-Mesbah R, Ter Horst GJ, Postema F, Wortel J, Buijs RM. Anatomical demonstration of the suprachiasmatic nucleus-pineal pathway. J Comp Neurol 1999;406:171-82.

72. Carrillo-Vico A, Calvo JR, Abreu P, Lardone PJ, García-Mauriño S, et al. Evidence of melatonin synthesis by human lymphocytes and its physiological significance: possible role as intracrine, autocrine, and/or paracrine substance. FASEB J 2004;18:537-9.

73. Carrillo-Vico A, Lardone PJ, Álvarez-Sánchez N, Rodríguez-Rodríguez A, Guerrero JM. Melatonin: buffering the immune system. Int J Mol Sci 2013;14:8638-83.

74. Hardeland R, Cardinali DP, Srinivasan V, Spence DW, Brown GM, et al. Melatonin--a pleiotropic, orchestrating regulator molecule. Prog Neurobiol 2011;93:350-84.

75. Erren TC, Falaturi P, Morfeld P, Knauth P, Reiter RJ, et al. Shift work and cancer. Dtsch Ärztebl Int 2010;107:657-62.

76. Davis S, Mirick DK, Stevens RG. Night shift work, light at night, and risk of breast cancer. J Natl Cancer Inst 2001;93:1557-62.

77. James P, Bertrand KA, Hart JE, Schernhammer ES, Tamimi RM, et al. Outdoor light at night and breast cancer incidence in the Nurses' Health Study II. Environ Health Perspect 2017;125:087010.

78. Johns LE, Jones ME, Schoemaker MJ, McFadden E, Ashworth A, et al. Domestic light at night and breast cancer risk: a prospective analysis of 105000 UK women in the generations study. Br J Cancer 2018;118:600-6.

79. Blask DE, Brainard GC, Dauchy RT, Hanifin JP, Davidson LK, et al. Melatonin-depleted blood from premenopausal women exposed to light at night stimulates growth of human breast cancer xenografts in nude rats. Cancer Res 2005;65:11174-84.

80. Hill SM, Belancio VP, Dauchy RT, Xiang S, Brimer S, et al. Melatonin: an inhibitor of breast cancer. Endocr Relat Cancer 2015;22:R183204.

81. Mao L, Dauchy RT, Blask DE, Dauchy EM, Slakey LM, et al. Melatonin suppression of aerobic glycolysis (Warburg effect), survival signalling and metastasis in human leiomyosarcoma. J Pineal Res 2016;60:167-77.

82. Reiter RJ, Rosales-Corral SA, Tan DX, Acuna-Castroviejo D, Qin L, et al. Melatonin, a full service anti-cancer agent: inhibition of initiation, progression and metastasis. Int J Mol Sci 2017;18:E843

83. Xiang S, Dauchy RT, Hauch A, Mao L, Yuan L, et al. Doxorubicin resistance in breast cancer is driven by light at night induced disruption of the circadian melatonin signal. J Pineal Res 2015;59:60-9. 
84. Teunis MA, Kavelaars A, Voest E, Bakker JM, Ellenbroek BA, et al. Reduced tumor growth, experimental metastasis formation, and angiogenesis in rats with a hyperreactive dopaminergic system. FASEB J 20021;16:1465-7.

85. Peters MAM, Walenkamp AME, Kema IP, Meijer C, de Vries EGE, et al. Dopamine and serotonin regulate tumor behavior by affecting angiogenesis. Drug Resist Updat 2014;17:96-104.

86. Ben-Shaanan TL, Azulay-Debby H, Dubovik T, Starosvetsky E, Korin B, et al. Activation of the reward system boosts innate and adaptive immunity. Nat Med 2016;22:940-4.

87. Ben-Shaanan TL, Schiller M, Azulay-Debby H, Korin B, Boshnak N, et al. Modulation of anti-tumor immunity by the brain's reward system. Nat Commun 2018;9:2723.

88. Barnes PJ. Anti-inflammatory actions of glucocorticoids: molecular mechanisms. Clin Sci Lond Engl 1979; 1998;94:557-72.

89. Sklar LS, Anisman H. Stress and coping factors influence tumor growth. Science 1979;205:513-5.

90. Sklar LS, Anisman H. Social stress influences tumor growth. Psychosom Med 1980;42:347-65.

91. Flint TR, Janowitz T, Connell CM, Roberts EW, Denton AE, et al. Tumor-induced IL-6 reprograms host metabolism to suppress anti-tumor immunity. Cell Metab 2016;24:672-84.

92. Oster H, Damerow S, Kiessling S, Jakubcakova V, Abraham D, et al. The circadian rhythm of glucocorticoids is regulated by a gating mechanism residing in the adrenal cortical clock. Cell Metab 2006;4:163-73.

93. Sood AK, Bhatty R, Kamat AA, Landen CN, Han L, et al. Stress hormone-mediated invasion of ovarian cancer cells. Clin Cancer Res 2006;12:369-75.

94. Shaashua L, Shabat-Simon M, Haldar R, Matzner P, Zmora O, et al. Perioperative COX-2 and \&amp;beta;-adrenergic blockade improves metastatic biomarkers in breast cancer patients in a phase-II randomized trial. Clin Cancer Res 2017;23:4651-61.

95. Heiden MGV, Cantley LC, Thompson CB. Understanding the warburg effect: the metabolic requirements of cell proliferation. Science 2009;324:1029-33

96. Warburg O. On the origin of cancer cells. Science 1956;123:309-14.

97. Warburg O, Wind F, Negelein E. The metabolism of tumors in the body. J Gen Physiol 1927;8:519-30

98. Bharadwaj S, Venkatraghavan L, Mariappan R, Ebinu J, Meng Y, et al. Serum lactate as a potential biomarker of non-glial brain tumors. J Clin Neurosci 2015 Oct;22:1625-7.

99. Ezeoke CC, Morley JE. Pathophysiology of anorexia in the cancer cachexia syndrome. J Cachexia Sarcopenia Muscle 2015;6:287-302.

100. Mariappan R, Venkatraghavan L, Vertanian A, Agnihotri S, Cynthia S, et al. Serum lactate as a potential biomarker of malignancy in primary adult brain tumours. J Clin Neurosci 2015;22:144-8.

101. Zhou L, Xie Z, Shao Z, Chen W, Xie H, et al. Modeling the relationship between baseline lactate dehydrogenase and prognosis in patients with extensive-disease small cell lung cancer: a retrospective cohort study. J Thorac Dis 2018;10:1043-9.

102. Cortes-Campos C, Elizondo R, Carril C, Martínez F, Boric K, et al. MCT2 expression and lactate influx in anorexigenic and orexigenic neurons of the arcuate nucleus. PLoS One 2013;8:e62532.

103. Cha SH, Lane MD. Central lactate metabolism suppresses food intake via the hypothalamic AMP kinase/malonyl-CoA signaling pathway. Biochem Biophys Res Commun 2009;386:212-6.

104. Chance WT, Dayal R, Friend LA, James JH. Elevated blood lactate is not a primary cause of anorexia in tumor-bearing rats. Nutr Cancer 2004;48:174-81.

105. Campos CA, Bowen AJ, Schwartz MW, Palmiter RD. Parabrachial CGRP neurons control meal termination. Cell Metab 2016;23:811-20.

106. Carter ME, Soden ME, Zweifel LS, Palmiter RD. Genetic identification of a neural circuit that suppresses appetite. Nature 2013;503:111-4.

107. Roman CW, Derkach VA, Palmiter RD. Genetically and functionally defined NTS to PBN brain circuits mediating anorexia. Nat Commun 2016;7:11905

108. Han S, Soleiman MT, Soden ME, Zweifel LS, Palmiter RD. Elucidating an affective pain circuit that creates a threat memory. Cell 2015;162:363-74.

109. Campos CA, Bowen AJ, Han S, Wisse BE, Palmiter RD, et al. Cancer-induced anorexia and malaise are mediated by CGRP neurons in the parabrachial nucleus. Nat Neurosci 2017;20:934-42.

110. De Vadder F, Kovatcheva-Datchary P, Goncalves D, Vinera J, Zitoun C, et al. Microbiota-generated metabolites promote metabolic benefits via gut-brain neural circuits. Cell 2014;156:84-96.

111. Routy B, Chatelier EL, Derosa L, Duong CPM, Alou MT, et al. Gut microbiome influences efficacy of PD-1-based immunotherapy against epithelial tumors. Science 2018;359:91-7.

112. Lakritz JR, Poutahidis T, Mirabal S, Varian BJ, Levkovich T, et al. Gut bacteria require neutrophils to promote mammary tumorigenesis. Oncotarget 2015;6:9387-96.

113. Levi F, Schibler U. Circadian rhythms: mechanisms and therapeutic implications. Annu Rev Pharmacol Toxicol 2007;47:593-628.

114 Mormont MC, Levi F. Cancer chronotherapy: principles, applications, and perspectives. Cancer 2003;97:155-69.

115. Borniger JC, Walker II WH, Gaudier-Diaz MM, Stegman CJ, Zhang N, et al. Time-of-day dictates transcriptional inflammatory responses to cytotoxic chemotherapy. Sci Rep 2017;7:41220.

116. Dycke KCGV, Nijman RM, Wackers PFK, Jonker MJ, Rodenburg W, et al. A day and night difference in the response of the hepatic transcriptome to cyclophosphamide treatment. Arch Toxicol 2015;89:221-31.

117. Lipp A, Tank J, Trottenberg T, Kupsch A, Arnold G, et al. Sympathetic activation due to deep brain stimulation in the region of the STN. Neurology 2005;65:774-5.

118. Parsons TD, Rogers SA, Braaten AJ, Woods SP, Tröster AI. Cognitive sequelae of subthalamic nucleus deep brain stimulation in Parkinson's disease: a meta-analysis. Lancet Neurol 2006;5:578-88.

119. Bower JE, Crosswell AD, Stanton AL, Crespi CM, Winston D, et al. Mindfulness meditation for younger breast cancer survivors: a randomized controlled trial. Cancer 2015;121:1231-40.

120. Palesh OG, Roscoe JA, Mustian KM, Roth T, Savard J, et al. Prevalence, demographics, and psychological associations of sleep disruption 
in patients with cancer: university of rochester cancer center-community clinical oncology program. J Clin Oncol 2010;28:292-8.

121. Ancoli-Israel S, Liu L, Marler MR, Parker BA, Jones V, et al. Fatigue, sleep, and circadian rhythms prior to chemotherapy for breast cancer. Support Care Cancer 2006;14:201-9.

122. Moore M, Packer M, Innominato PF, Koopman C, Kesler S, et al. Sleep, circadian disruption and neurocognition in breast cancer (BC) patients undergoing chemotherapy. J Clin Oncol 2016;34:10072.

123. Zhu Y, Brown HN, Zhang Y, Stevens RG, Zheng T. Period3 structural variation: a circadian biomarker associated with breast cancer in young women. Cancer Epidemiol Prev Biomark 2005;14:268-70.

124. Dedert E, Lush E, Chagpar A, Dhabhar FS, Segerstrom SC, et al. Stress, coping, and circadian disruption among women awaiting breast cancer surgery. Ann Behav Med 2012;44:10-20.

125. Pereira J, Hanson J, Bruera E. The frequency and clinical course of cognitive impairment in patients with terminal cancer. Cancer 1997;79:835-42.

126. Hutchinson AD, Hosking JR, Kichenadasse G, Mattiske JK, Wilson C. Objective and subjective cognitive impairment following chemotherapy for cancer: a systematic review. Cancer Treat Rev 2012;38:926-34.

127. Von Ah D, Habermann B, Carpenter JS, Schneider BL. Impact of perceived cognitive impairment in breast cancer survivors. Eur J Oncol Nurs 2013;17:236-41.

128. Jenkins V, Shilling V, Deutsch G, Bloomfield D, Morris R, et al. A 3-year prospective study of the effects of adjuvant treatments on cognition in women with early stage breast cancer. Br J Cancer 2006;94:828-34.

129. Villarreal-Garza C, Shaw-Dulin R, Lara-Medina F, Bacon L, Rivera D, et al. Impact of diabetes and hyperglycemia on survival in advanced breast cancer patients. J Diabetes Res 2012;2012:e732027.

130. Larsson SC, Mantzoros CS, Wolk A. Diabetes mellitus and risk of breast cancer: a meta-analysis. Int J Cancer 2007;121:856-62.

131. Schoemaker MJ, Nichols HB, Wright LB, Brook MN, Jones ME, et al. Association of body mass index and age with subsequent breast cancer risk in premenopausal women. JAMA Oncol 2018;4:e181771.

132. Muti P, Quattrin T, Grant BJB, Krogh V, Micheli A, et al. Fasting glucose is a risk factor for breast cancer: a prospective study. Cancer epidemiol prev biomark 2002;11:1361-8.

133. Xuan C, Shamonki JM, Chung A, DiNome ML, Chung M, et al. Microbial dysbiosis is associated with human breast cancer. PLoS One 2014;9:e83744.

134. Goedert JJ, Jones G, Hua X, Xu X, Yu G, et al. Investigation of the association between the fecal microbiota and breast cancer in postmenopausal women: a population-based case-control pilot study. J Natl Cancer Inst 2015;107:djv147.

135. Luu TH, Michel C, Bard JM, Dravet F, Nazih H, et al. Intestinal proportion of blautia sp. is associated with clinical stage and histoprognostic grade in patients with early-stage breast cancer. Nutr Cancer 2017;69:267-75.

136. Minelli EB, Beghini AM, Vesentini S, Marchiori L, Nardo G, et al. Intestinal microflora as an alternative metabolic source of estrogens in women with uterine leiomyoma and breast cancer. Ann N Y Acad Sci 1990;595:473-9.

137. Pierce BL, Ballard-Barbash R, Bernstein L, Baumgartner RN, Neuhouser ML, et al. Elevated biomarkers of inflammation are associated with reduced survival among breast cancer patients. J Clin Oncol 2009;27:3437-44.

138. Murri AMA, Bartlett JMS, Canney PA, Doughty JC, Wilson C, et al. Evaluation of an inflammation-based prognostic score (GPS) in patients with metastatic breast cancer. Br J Cancer 2006;94:227-30.

139. McMillan DC, Elahi MM, Sattar N, Angerson WJ, Johnstone J, et al. Measurement of the systemic inflammatory response predicts cancerspecific and non-cancer survival in patients with cancer. Nutr Cancer 2001;41:64-9.

140. Iyengar NM, Zhou XK, Gucalp A, Morris PG, Howe LR, et al. Systemic correlates of white adipose tissue inflammation in early-stage breast cancer. Clin Cancer Res 2016;22:2283-9.

141. Pyter LM, Pineros V, Galang JA, McClintock MK, Prendergast BJ. Peripheral tumors induce depressive-like behaviors and cytokine production and alter hypothalamic-pituitary-adrenal axis regulation. Proc Natl Acad Sci U S A 2009;106:9069-74.

142. Norden DM, Devine R, Bicer S, Jing R, Reiser PJ, et al. Fluoxetine prevents the development of depressive-like behavior in a mouse model of cancer related fatigue. Physiol Behav 2015;140:230-5.

143. Norden DM, Bicer S, Clark Y, Jing R, Henry CJ, et al. Tumor growth increases neuroinflammation, fatigue and depressive-like behavior prior to alterations in muscle function. Brain Behav Immun. 2015;43:76-85.

144. Grossberg AJ, Zhu X, Leinninger GM, Levasseur PR, Braun TP, et al. Inflammation-induced lethargy is mediated by suppression of orexin neuron activity. J Neurosci 2011;31:11376-86.

145. Huan H, Wen X, Chen X, Wu L, Wu L, et al. Sympathetic nervous system promotes hepatocarcinogenesis by modulating inflammation through activation of alpha1-adrenergic receptors of Kupffer cells. Brain Behav Immun 2017;59:118-34.

146. Basu S, Sarkar C, Chakroborty D, Nagy J, Mitra RB, et al. Ablation of peripheral dopaminergic nerves stimulates malignant tumor growth by inducing vascular permeability factor/vascular endothelial growth factor-mediated angiogenesis. Cancer Res 2004;64:5551-5.

147. Filipski E, King VM, Li X, Granda TG, Mormont MC, et al. Disruption of circadian coordination accelerates malignant growth in mice. Pathol Biol (Paris) 2003;51:216-9.

148. Khalyfa A, Almendros I, Gileles-Hillel A, Akbarpour M, Trzepizur W, et al. Circulating exosomes potentiate tumor malignant properties in a mouse model of chronic sleep fragmentation. Oncotarget 2016;7:54676-90. 